\title{
Analysis of Performance and Competitiveness of Water Hyacinth Crafts Based on Product Differentiation, Creativity, and Green Entrepreneurial
}

\author{
Siti Aliyati Albushairi ${ }^{1}$, Nuril Huda ${ }^{2, *}$ \\ ${ }^{1}$ Faculty of Economics and Business, Lambung Mangkurat University, Banjarmasin, Indonesia \\ ${ }^{2}$ Faculty of Economics and Business, Lambung Mangkurat University, Banjarmasin, Indonesia \\ *Corresponding author. Email: nurilhuda@ulm.ac.id
}

\begin{abstract}
This study aims to analyze the effect of product differentiation, creativity, and green entrepreneurial orientation on performance and competitiveness. This study was conducted in North Hulu Sungai Regency, South Kalimantan Province. The sample is set at 135 respondents. Data was sourced from observations, interviews, and questionnaires. SEM PLS was used in this study. The results show that product differentiation, creativity, and green entrepreneurial orientation affect performance. Creativity increases competitiveness. SMEs need to empower employees, product innovation, training, and factory waste disposal.
\end{abstract}

Keywords: Performance, competitiveness, product differentiation, creativity and green entrepreneurial orientation.

\section{INTRODUCTION}

The creative economy contributes to the total national economy by 7.38 percent, with a total Gross Domestic Product (GDP) of around Rp. 852.24 trillion [1]. The creative economy, which consists of culinary, fashion and crafts, contributes to GDP. The culinary sub-sector contributed $41.69 \%$, the fashion sub-sector contributed $18.15 \%$ and the handicraft sub-sector contributed $15.70 \%$. One type of craft in South Kalimantan is water hyacinth. This industry can provide great added value to the economy. The prospect and development of this industry in South Kalimantan are quite good since South Kalimantan has a lot of swamp area which produces a lot of water hyacinth plants. Various types of products are produced such as hats, bags, tissue holders, guest tables and chairs, oysters, and so on. Its products are sold to local people, outside the region and abroad.

The challenges faced by water hyacinth crafts such as making products that sell well in local and foreign markets, human resources, marketing, and others. Therefore, the author tries to examine more deeply related to the three aspects such as product differentiation, employee creativity, and green entrepreneurial, to achieve performance and competitiveness.
Product differentiation affects performance [2]. A study from [3] found that differentiation strategy, environmental generosity was positively related to performance. Creativity affects performance [4] and competitiveness [5]. Small industries which focus on creativity produce better performance than before [6]. Organizations need to have creative people as a renewable resource. [7] explains that creative people can increase competitive advantage. Green Entrepreneurial is a person who has a soul that is focused on preserving nature and being eco-friendly.

Hulu Sungai Utara is one of the areas in South Kalimantan. The area has abundant water hyacinth plants. The plant is a weed but can be used to make high-value craft products. Water hyacinth products are unique products, have aesthetic value, have elements of art or beauty, and use natural raw materials. The raw materials are obtained from the surrounding environment.

\section{LITERATURE REVIEW}

\subsection{Differentiation Product}

Companies need to make a differentiation strategy to win the competition in an industry. Differentiation strategy is a strategy to create a product that has value 
and uniqueness which is to differentiate the product from competitors. This strategy is used by the company if the company wants to compete with other companies which focus on product uniqueness. The differentiation strategy is structured to create a strategic position in the market. A company is said to be successful in mapping if it can effectively differentiate itself from its competitors by providing superior value to its customers along with cost control. This strategy can reduce competition in the market if the company runs it well. Studies by [2], show that product differentiation affects performance. The formulation of the hypothesis is:

\section{$\mathrm{H}_{1}$ : Differentiation affects performance}

\subsection{Creativity}

Employee creativity is very important in an organization. Creative employees are people who have new ideas, are flexible, have better skills, understand and adapt to new technologies. According to [6], products that are unique as a result of the creative process become competitive products for companies. He further explained that to expand their position in the market, companies need to be innovative. This can be done by increasing the value of the product. Companies can increase the value of the product by leveraging the symbolic and cultural values embedded in the product to strengthen its competitive position. Creativity affects performance and competitiveness. Creativity affects performance [4] and competitiveness [5]. [8] explains that employee creativity in organizations is needed to create competitiveness. The proposed hypothesis is as follows:

\section{$\mathrm{H}_{2}$ : Creativity affects performance \\ $\mathrm{H}_{3}$ : Creativity affects competitiveness.}

\subsection{Green Entrepreneurial Orientation}

Innovation plays a role in improving performance and sustainability. The study of [9] explains that policymakers and managers are starting to realize the importance of green innovation and green entrepreneurship to improve business performance and sustainability. A green entrepreneurial orientation plays a role in helping managers understand and know the factors that affect sustainable business performance. The indication is that with green entrepreneurship, the company becomes wise to the surrounding environment. This means that the company cares about the environment by utilizing plants to become products that have a high selling value. The strategic implication is that people's welfare will increase. Green entrepreneurial innovation affects performance. The results of research from [9] and [10] show that green entrepreneurial orientation affects performance. The proposed hypothesis formulation is:

$\mathrm{H}_{4}$ : Green entrepreneurial orientation affects performance

\subsection{Performance and Competitiveness}

The company designs strategies to create performance and competitiveness. Competitiveness has an important role to achieve long-term success and sustainability. Competitive advantage leads to product advantages that have superior value perceived by customers or have achieved the production of a low cost. [11] stated about the factors which influence competitive advantage, those are (1) situational factors; (2) demand conditions; (3) the nature of market demand; (4) related and supporting industries; (5) Company strategy, organizational structure, and competition. A study from [4] shows that performance affects the competitiveness situation.

$\mathrm{H}_{5}$ : performance affects the competitiveness

\subsection{Framework}

This study designs a model that is formed from product differentiation, green entrepreneurial orientation and creativity to achieve performance and competitiveness. The model is shown on figure 1.

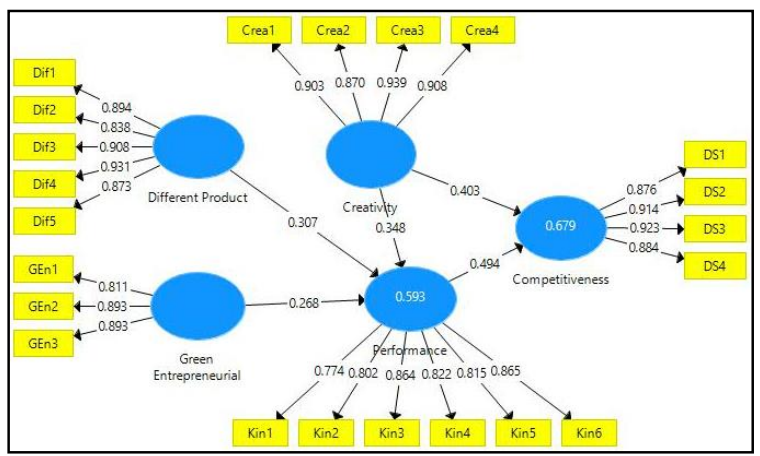

Figure 1. Conceptual Framework

\section{RESEARCH METHODS}

Quantitative research with an approach to the type of explanatory research. According to [12], explanatory research is used to explain the causal relationship between the influencing variables. Data were collected through observation, interviews, and questionnaires. Questionnaire items consist of statements about product differentiation, green 
entrepreneurial orientation, creativity, performance, and competitiveness. The ranking is using a Likert scale with a score of 1-5 points. Primary data sourced from craftsmen. The research location is in North Hulu Sungai district. The sampling technique is purposive sampling, the criteria are craftsmen who produce in North Hulu Sungai district (2) creative and innovative craftsmen. SEM PLS was used in this study. The sample taken is 135 respondents. The basis is referring to the opinion of Hair, et. al. (1992) in Ferdinand (2000), stated that the number of samples that can be taken for Structural Equation Modeling (SEM) is 100200 , and if the sample size is too large it tends to be biased. The statement item for differentiation questionnaire refers to [13], creativity questionnaire refers to [8], green entrepreneurial questionnaire refers to [10], performance questionnaire refers to [14], competitiveness questionnaire refers to [15].

\section{RESULTS AND DISCUSSION}

Characteristics of respondents are dominated by women $(74.1 \%)$, elementary school education $(40.7 \%)$, age over 40 years $(46,22 \%)$, work as craftsman $(88.1 \%)$, duration of being an entrepreneur three years $(11.1 \%)$, and the origin of skills from talent and descent the marketing area is South Kalimantan $(80,7 \%)$, the promotion through social media is $74.8 \%$.

\subsection{Confirmatory Factor Analysis/ Measurement Model (Measurement of Indicator Variables)}

According to [16], the evaluation of the measurement model uses convergent validity, discriminant validity, and composite reliability. [16] explained that convergent validity was measured by a loading factor with a loading factor value above 0.7 and a loading factor above 0.6 for exploratory research.

Table 1 shows that the results have met the requirements of convergent validity because all factor loads are above 0.70 . Thus, researchers can conduct further testing. The discriminant validity is shown in Table 2.

The construct that has the highest loading factor is competitiveness. AVE and CR values can be seen in Table 3 below. Based on Table 3, all constructs meet the criteria of being reliable. This is indicated by the value of CR above 0.70 and AVE above 0.50 [16].

Table 1. Outer Loading with Convergent Validity Method

\begin{tabular}{|l|l|l|l|l|l|}
\hline & Competitiveness & Creativity & $\begin{array}{c}\text { Differentiation } \\
\text { Product }\end{array}$ & $\begin{array}{c}\text { Green } \\
\text { Entrepreneurial }\end{array}$ & Performance \\
\hline Crea 1 & & 0.903 & & & \\
\hline Crea 2 & & 0.870 & & & \\
\hline Crea 3 & & 0.939 & & & \\
\hline Crea 4 & & 0.908 & & & \\
\hline CS 1 & 0.876 & & & & \\
\hline CS 2 & 0.914 & & & & \\
\hline CS 3 & 0.923 & & & & \\
\hline CS 4 & 0.884 & & & & \\
\hline Df1 & & & 0.894 & & \\
\hline Df2 & & & 0.838 & & \\
\hline Df3 & & & 0.908 & & \\
\hline Df & & & 0.931 & & \\
\hline Df5 & & & 0.873 & & \\
\hline G1 & & & & 0.811 & \\
\hline G2 & & & & 0.893 & \\
\hline G3 & & & & 0.893 & \\
\hline P1 & & & & & 0.874 \\
\hline P2 & & & & & 0.864 \\
\hline P3 & & & & & 0.822 \\
\hline P4 & & & & & \\
\hline P5 & & & & & \\
\hline P6 & & & & & \\
\hline
\end{tabular}


Table 2. Discriminant validity (cross-loading)

\begin{tabular}{|c|c|c|c|c|c|}
\hline & Competitiveness & Creativity & $\begin{array}{c}\text { Differentiation } \\
\text { Product }\end{array}$ & $\begin{array}{c}\text { Green } \\
\text { Entrepreneurial }\end{array}$ & Performance \\
\hline Competitiveness & 0.899 & & & & \\
\hline Creativity & 0.741 & 0.905 & & & \\
\hline $\begin{array}{c}\text { Different } \\
\text { Product }\end{array}$ & 0.764 & 0.745 & 0.889 & & \\
\hline $\begin{array}{c}\text { Green } \\
\text { Entrepreneurial }\end{array}$ & 0.501 & 0.403 & 0.431 & 0.867 & \\
\hline Performance & 0.770 & 0.685 & 0.682 & 0.541 & 0.824 \\
\hline
\end{tabular}

Table 3. CR and AVE

\begin{tabular}{|c|c|c|c|}
\hline & Cronbach's Alpha & Composite Reliability & $\begin{array}{c}\text { Average Variance } \\
\text { Extracted (AVE) }\end{array}$ \\
\hline Competitiveness & 0.921 & 0.944 & 0.809 \\
\hline Creativity & 0.927 & 0.948 & 0.820 \\
\hline Different Product & 0.934 & 0.950 & 0.791 \\
\hline Green Entre & 0.835 & 0.900 & 0.751 \\
\hline Performance & 0.906 & 0.927 & 0.680 \\
\hline
\end{tabular}

\subsection{Structural Model Setting (Inner Model)}

Structural model (inner model) is used to see the relationship between the construct, significance score, and R-square of the research model. The R-square values for each construct are shown in Table 4 below:

Table 4. Inner Model

\begin{tabular}{|c|c|c|}
\hline Construct & R-Square & R Adjusted \\
\hline Competitiveness & 0.679 & 0.674 \\
\hline Performance & 0.593 & 0.584 \\
\hline
\end{tabular}

For the competitiveness construct with an R-square value of 0.679 . This means that performance explains $67.9 \%$ of competitiveness. The R-square value for the performance construct is 0.593 which means product differentiation, green entrepreneurship, and creativity explained the performance of $59.3 \%$.

\subsection{Hypothesis Test}

A hypothesis is accepted or rejected, by looking at its significance ( $\mathrm{p}$-value) and the comparison between $\mathrm{t}$ - arithmetic and $\mathrm{t}$ - table (alpha 5\%). In this research, all proposed hypotheses were accepted, which can be indicated from the analysis result in Table 5 . Hypothesis H1 is accepted. This is indicated by the value of $\mathrm{t}$-count $=3.008>1.96$. This shows that product differentiation is positively and significantly related to performance. Hypothesis 2 is accepted with the t-count value of $3.296>1.96$, meaning that creativity has a significant and positive effect on performance. Hypothesis 3 is accepted, with the tcount value of $4.824>1.96$, meaning that creativity has a significant and positive effect on competitiveness. Hypothesis 4 is accepted with the tcount value of $3.502>1.96$, meaning that green entrepreneurial orientation is positively and significantly related to performance. Hypothesis 5 is accepted where $t$ count $5.884>1.96$, meaning that performance has a significant and positive effect on competitiveness.

\section{DISCUSSION}

The water hyacinth craft industry plays an important role in creating jobs for the surrounding community. This type of industry has high creativity

Table 5. Result for inner weights

\begin{tabular}{|l|c|c|c|c|c|}
\hline & $\begin{array}{c}\text { Original } \\
\text { Sample }\end{array}$ & $\begin{array}{c}\text { Sample } \\
\text { Mean (M) }\end{array}$ & $\begin{array}{c}\text { Standard } \\
\text { Deviation } \\
\text { (STDEV) }\end{array}$ & $\begin{array}{c}\text { T } \\
\text { Statistic(JO/ } \\
\text { STDEV) }\end{array}$ & P - Value \\
\hline Diferentiation Product $\rightarrow$ Performance & 0.307 & 0.312 & 0.102 & 3.008 & 0.003 \\
\hline Creativity $\rightarrow$ Performance & 0.348 & 0.338 & 0.106 & 3.296 & 0.001 \\
\hline Creativity $\rightarrow$ Compettitiveness & 0.403 & 0.397 & 0.084 & 4.824 & 0.000 \\
\hline Green Entrepreneurial $\rightarrow$ Performance & 0.268 & 0.273 & 0.077 & 3.502 & 0.001 \\
\hline Performance $\rightarrow$ Competitiveness & 0.494 & 0.501 & 0.084 & 5.884 & 0.000 \\
\hline
\end{tabular}


considering that its products have their uniqueness. The author conducted this study to analyze the effect of product differentiation, creativity, and green entrepreneurial orientation on performance and competitiveness. And determine the right strategy to win the competition in an industry. The focus of this research is on the craft industry made from water hyacinth. This product is unique, aesthetic and has the high potential to be developed in swampy areas such as South Kalimantan. The resulting product has the high potential to attract local, outside the area and foreign tourists to buy.

In this study, hypothesis testing needs to be done to answer the research objectives. Test the hypothesis by looking at the comparison between the $t$ count and the $\mathrm{t}$ table. If $\mathrm{t}$ count $>\mathrm{t}$ table then the hypothesis is accepted and vice versa. In this study, five hypotheses were developed and all of them were accepted. The first hypothesis (H1) is accepted, meaning that product differentiation has a significant effect on performance. especially those related to products that have attractive designs, colors according to demand, high-quality products, high durability products, and the model is following the trend in fashion. These results support research from [2].

Hypothesis 2 and hypothesis 3 are accepted where creativity has a significant effect on performance and competitiveness. This is mainly related to the vastness of ideas in product designs, the originality of the product, uniqueness, and the variety of colors and motifs. These results support the research of [4].

Hypothesis 4 is accepted. where a green entrepreneurial orientation has a significant effect on performance. This is mainly related to frequently doing new things such as design, coloring motifs, always developing environmentally friendly products, and being at the forefront of introducing environmentally friendly products. These results support the research of [9] [10].

Hypothesis 5 is accepted. where performance has a significant effect on competitiveness. This is mainly related to products that have an aesthetic appearance, products produced according to specifications, the products are more creative than competitors, the products are more innovative than competitors, having higher market domination, the resources are managed and utilized to produce optimal output, increased efficiency in the use of materials. raw. These results support the research of [4].

\section{CONCLUSIONS}

The developed model has theoretical and empirical implications. Theoretical implications can strengthen theoretical concepts and provide empirical data to support previous research, especially deepening studies on performance. The focus is on the water hyacinth industry in South Kalimantan. This research shows that the industry needs to empower employees through (1) management and leadership using employee feedback to make improvements; (2) the employees have sufficient involvement in decisions that affect their work; (3) the Management empowers employees to give them a sense of accomplishment; (4) the employees understand how their efforts contribute to the overall goals and strategies of the organization. 5) the employees have the support and authority to make the decisions needed to complete the assigned tasks.

Related to product differentiation, SMEs need to look for other uniqueness or product innovations to compete in the market. For the aspect of creativity, SMEs need to involve employees in training activities, for example, those organized by the government and the private sector. Related to green entrepreneurship, SMEs need to provide enlightenment to employees to always produce eco-friendly products and waste treatment sites. This is intended to make the environment remains sustainable and teaches us to be smart and wise towards the environment. The ultimate goal is prosperity.

\section{ACKNOWLEDGMENT}

The researcher is a recipient of a PDWM research grant from Lambung Mangkurat University in 2021. Sourced from ULM PNBP funds.

\section{REFERENCES}

[1] T. Munaf, Kuliner, Kriya dan Fashion Penyumbang Terbesar Ekonomi Kreatif , 2021 Available from: https://kominfo.go.id, .

[2] ELIKWU, et al., "Effect of Differentiation Strategy on Performance Of Selected Small Scale Manufacturing Firms in Nigeria," .International Journal of Social Science and Economic Research, vol. 5, no. 8, 2020.

[3] A. H. Gorondutse, and Haim. "Influence of Differentiation Strategy on Performance of Hotels: the moderating Role of Environmental Munificence," Journal of Business and Retail Management Research, vol.11, no. 4, 2017. 
[4] S. Albushairi, H. Nuril, and Ahmad. "Improving Performance, Competitiveness, and Well-being in the Creative Industry Based on Local Wisdom," Journal of Innovation, Creativity and Change., vol. 15, no. 9, 2021.

[5] I. F. Sulaiman, N.H. Che, M. B. Ibrahim, \& S. S. S. Hasan, "Impact of Creativity to Organizational Competitiveness," International Journal of Humanities and Social Science, vol 5. no 8, 2015.

[6] D. S. Budiarto, M. A. Prabowo, P. K. B. Purnami, "Business Linearity and Creativity to Improve MSMEs Entrepreneurial Performance," Journal of Innovation, Creativity, and Change, vol. 14, issue 4,2020 .

[7] E. Astuty, and Suryana, "Creative People as a New Source of Competitive Advantage in the Creative Industry," Sebelas March Business Review, vol.2, issue 1, 2018.

[8] Sutapa, and Mulyana, "The Role of Market Orientation, Creativity and Innovation in Creating Competitive Advantages and Creative Industry Performance," Jurnal Dinamika Manajemen, vol. 8, no. 2, pp. 152-166. 2017.

[9] C. Muangmee, et al., "Green Entrepreneurial Orientation and Green Innovation in Small and Medium-Sized Enterprises (SMEs)," Social Sciences, 2021.

[10] O. Fatoki, "Green Entrepreneurial Orientation and Firm Performance in South Africa," South Africa, Entrepreneurship2-- and Sustainability Issues, vol 7 no.1, pp. 247-262, 2019.

[11] G. G. Dess, G. T. Lumpkin, and B. Alan,. "Strategic Management: Text and Cases," 2007.

[12] Sugiyono, Metode Penelitian Kuantitatif Kualitatif dan R\&B. Bandung: Alfabeta, 2016.

[13] K. Harahap, S. J. Raharja, O. S. Abdoellah, and A. Muftiadi, "Effect of Product Differentiation Implementation on Marketing Performance on Apparel Industry in Bandung City," OSR Journal of Business and Management, vol.19, issue 5, pp. 41-50, 2017.

[14] P. E. J. Jaya, M. S. Utama, I. G. W. M. Yasa, and N. N. Yuliarni, "Determinants of Creative Product Performance, Competitiveness, and Well-Being of Small and Medium Enterprises in
Denpasar," Journal of Innovation, Creativity and Change, vol 13, issue 12, pp. 621-635, 2020.

[15] N. Huda, S. Aliyati and Ahmad, "Development of the Business Model of Hyacinth Crafts Industry to Improve Competitive Advantage and Performance in a Wetland Environment," Journal of Innovation, Creativity and Change, vol 14, issue 9, pp. 447-465, 2020.

[16] Ghozali, and Hengky, "Partial Least Squares Konsep, Teknik Dan Aplikasi Menggunakan Program SmartPLS 3.0 Untuk Penelitian,” 2015. 